\title{
The Impact of Asian Drivers on the Developing World
}

\author{
IDS Asian Drivers Team*
}

\section{Key research questions}

The past 500 years of global history have been characterised by changing patterns of global dominance. In the late sixteenth century, China accounted for around 30 per cent of global gross domestic product (GDP), compared with a share of around 20 per cent for Western Europe and less than 5 per cent for Japan; at that time, North America barely featured as a production base (Dahlman and Aubert 2001). During the eighteenth and nineteenth centuries, Western Europe in general (and the UK in particular) grew to dominate the global economy, with their role being supplanted from the late nineteenth century by the US.

From the late twentieth century, Asian economies, with more than half of the global population, began to play an increasingly important role as global producers. This revival began in Japan after the 1960s, and then spread to a limited number of small and medium-sized East Asian economies during the last quarter of the century. At the dawn of the new millennium, the momentum of Asia has been significantly strengthened by the very rapid growth of two very large economies: China and India, each with around 20 per cent of the global population, have seen sustained rates of economic growth exceeding 7 per cent annually. But it is not just these two economies which underlie Asia's growing presence in the global economy. China in particular is integrated into a regional system of production involving a number of medium-sized economies such as Thailand and Vietnam, and India is actively beginning to pursue links with other South Asian regional economies. We refer to these newly dynamic and generally large Asian economies as the Asian Drivers.

These Asian Drivers are likely to have a significant impact on the global economy for three major reasons. The first arises as a consequence of their growing competitiveness, their size and their rapid growth. This is reflected not just in their GDP and share of global trade, but also in their command over key strategic resources such as investment and foreign exchange; together, for example, China and India have foreign exchange reserves of more than US $\$ 700 \mathrm{bn}$. As a result, the Asian Drivers have a non-marginal impact on a range of factor and product markets.

The second way in which these newly dynamic Asian economies will have an impact on the global economy is as a result of their conduct as investors, buyers and in institutions of global governance. In many sectors, investors from the Asian Drivers are beginning to play an important role in other developing economies and in the coordination of global production networks. Buyers located in these newly dynamic economies are beginning to provide new avenues for both existing and new products sourced from other developing economies. Asian Driver governments are already playing an increasingly important role in shaping the global economy. They participate actively in a variety of "rules-making bodies" such as the World Trade Organization (WTO) and the International Monetary Fund (IMF) in discussion on global climate change. It is likely that their roles in these institutions will grow in importance as their economic power strengthens further. It is also possible that they may begin to play a particular and distinctive role, perhaps developing positions in opposition to the currently dominant views of the North American and Western European economies. It is not too fanciful to see the emergence of what might be called a "Beijing Consensus" running in some cases against the currently hegemonic Washington Consensus, which dominates the institutions of global (and often national) governance. Finally, non-governmental 
actors from these economies are also beginning to play a role in the rules governing private sector economic interchanges, and in NGO-fora.

And, third, as a consequence of the impacts of the Asian Drivers on the global economy, lowincome economies which previously saw their future as lying in promoting North-South links, are now increasingly looking towards Asia and/or to their regions as sources of future dynamism.

There is increasing recognition of the growing power of these Asian Drivers, reflected in all of the major newspapers and financial journals. How will the Asian Drivers use their foreign exchange surpluses? Will they trigger a run on the dollar as they switch into the Euro? How will the global electronics industry be affected by the rise of Chinese producers such as Lenovo (which recently took over IBM's PC division), or Huawei Technologies, which has a rapidly growing presence in the supply of global telecommunications networks? What impact will India's growing presence in the global service sector have on white-collar and professional employment in the high-income economies?

But in all this flurry of activity on the impact of the Asian Drivers on the global economy, few are asking the question: what impact will they have on the developing world? This question is particularly apposite given the commitment of the global community to halve the incidence of global poverty by 2015 .

This article sets out the outlines of a globally networked research programme. It provides answers to five major sets of challenges posed to low-income economies by the rise of the Asian Drivers:

1. What are the consequences for their economic growth?

2. Who are likely to be the losers and winners from the growing dynamism of the Asian Drivers, within and between low-income economies, and within and between regional clusters of lowincome economies?

3. Given these growth and distributional impacts, what are the implications for development strategies in developing economies?

4. How should developing countries engage with the global economy in general, and the Asian Drivers in particular?

5. Given their rapid growth and size, what are the implications of this shift in global power for institutions of local, national, regional and global governance, in the public, private and nongovernmental sectors?

We begin this outline of a research programme by focusing on a taxonomy of linkages through which the Asian Drivers might affect developing economies. We identify key knowledge gaps and briefly establish the principles of a methodology appropriate to answer the five central questions set out above. We conclude by establishing the nature of the network relations involved in this research programme.

\section{A taxonomy of impacts}

We can identify four dominant vectors through which the dynamism of the Asian Drivers has an impact on growth and distribution in low-income economies and regions:

- Production and trade flows
- Einancial flows
- Environmental spillovers
- Global and regional governance.

There are a number of features which are common to each of these vectors. First, the scope of these impacts ranges from the micro-, through the meso- to the macro-level. For example, following the abolition of Multifibre Arrangement (MFA) quotas, the potentially very rapid rise of Asian Driver producers in the clothing sector affects individual producers in other developing economies, groups of producers (such as African exporters to the US under the African Growth Opportunities Act (AGOA) arrangements), and the structure of the global textiles and apparel sector as a whole. Second, these impacts may be both direct and indirect. Indeed indirect effects may often have a bigger impact on growth in developing countries than more obvious but quantitatively less significant direct effects. For example, although switches in foreign exchange reserves by China and India may directly only affect growth in the US and the EU, they may have a significant indirect impact on the capacity of other low-income economies to export to these large markets. Third, low-income economies are affected differentially by the competitiveness and growth of the Asian Drivers. In some cases, there may be complementary effects, perhaps because producers in other economies benefit from the demand for their outputs from the 
Asian Drivers, are included in regional value chains or participate in joint-action in institutions of global governance. In other cases, their interests may be competitive, for example, when Asian Drivers exclude other developing economies from access to global markets or investment resources. Fourth, although the four vectors represent different ways in which the growth of the Asian Drivers can be seen to affect other developing economies, they are often interconnected. For example, foreign direct investment (FDI) flows are closely linked to changing patterns of global trade, and to the clustering of economic activity which leads to adverse environmental spillovers. And, finally, each of these four vectors reflects not just flows of resources, but also the exercise of power. China and India not only command more than US $\$ 700 \mathrm{bn}$ of foreign exchange resources, but have the capacity to affect key exchange rates, especially with respect to the dollar; China and India are not just exporters of manufactures, but increasingly are host to powerful firms with a growing global footprint.

\subsection{Production and trade flows}

In recent years, the Asian Drivers have seen a significant increase in their share of global production and trade. For example, between 1985 and 2000, China's share of global manufacturing value added grew from 1.4 to 7.0 per cent, and its share of developing country manufacturing value added from 10.2 to 29.3 per cent. During the same period, its share of global manufactured exports grew from 1.0 to 6.5 per cent, and from 7.6 to 24 per cent, respectively (UNIDO 2002). In commodities, between 2000 and 2003, China's share of the increase in global demand for aluminium, steel, nickel and copper was 76 per cent, 95 per cent, 99 per cent and 100 per cent, respectively (Kaplinsky 2005). Similar trends can be discerned in many agricultural and service sectors. India has seen a major increase in servicesector exports and in agriculture, of the developing country members of the Asian Development Bank; 12 are net food exporters and 22 are net food importers (Wilson 2002).

The growing presence of the Asian Drivers in global trade flows reflects a variety of value chains. In some cases, exports take place within the internalised operations of transnational corporations (TNCs). In other cases, production and exports arise from the presence of increasingly large, dynamic and powerful firms with roots in Asian Driver economies. Particularly in the case of China, many sectors exports emerge from regional value chains, involving coordinated production between plants in different economies and resulting in deepening regional integration. Thus, East Asian intra-regional trade rose from 24 to 35 per cent between 1985 and 2001 (Ng and Yeats 2003). Much of China's growth in manufactured exports, especially in electronics, incorporates components produced in surrounding economies (Lall and Abaladejo 2004).

These regional value chains are examples of the complementary effect of the growth of production and trade in the Asian Drivers. So too is their demand for inputs sourced from other low-income economies; Brazilian iron ore and Argentinean soya exports are expanding rapidly as a result of China's voracious demand for inputs. But at the same time, the dynamism of production and exports from the Asian Drivers has had significant competitive impacts on other low-income countries. Their growing competitiveness has squeezed product prices in many sectors in which developing countries participate; between 1988 and 2002, the greater the share of China in EU imports, the more likely that the prices of these products fell (Kaplinsky 2005). It has also resulted in many low-income economies being squeezed out of final markets, notably in the case of the global clothing sector in those sub-sectors in which quotas have been removed. Low income economies may also be squeezed out of resource-input markets by rising prices and the internalised value chains of Asian Driver firms. For example, both Chinese and Indian oil and gas companies are rapidly developing production links in Asia and elsewhere to ensure long-term supplies of energy, with unexplored consequences, not just for the global supplydemand balance, but for the access of other developing countries to these inputs.

A striking recent feature of the growth of these Asian Drivers is the growing power and presence of their corporate sectors. Unlike many other developing economies, exports from the Asian Drivers are increasingly being driven by locally owned firms. In many cases these firms have the strategic drive to become significant global players and are reluctant to be relegated to the role of producing to the designs emanating from highincome economies (a generally competitive and 
low-margin niche filled by many developing economy firms). Hence, they are not only expanding their external operations, for example, in energy, in pharmaceuticals, telecommunications, in software and in finance, but do so by becoming foreign investors themselves, often in other developing economies.

\subsection{Financial flows}

The impact of financial flows on other developing economies resulting from the dynamism of the Asian Drivers shows the importance of examining indirect and macroeconomic factors. The magnitude of the surpluses held by the Asian Drivers has meant that they have a major impact on the trajectory and stability of the global economy, with profound implications for other developing economies. Since the late 1990s, buoyant demand in the global economy has been facilitated by the ability of the US (and to some extent the UK) economy to act as an engine of demand for global production. This not only benefits the direct exports of low-income economies to these current account-deficit countries, but also to current account-surplus economies whose surpluses arise from their trade with the US (and the UK).

The manner in which the Asian Drivers choose to handle these surpluses will have a major impact on the trajectory of the global economy, both with regard to the speed and nature of growth. Should they, for example, move their assets out of the dollar, this might have a range of direct effects (reducing demand in the US) and indirect effects (making EU exports less competitive). Unless growth is increased significantly in other regions, this could imply a large fall in low-income countries' exports as well as their growth. In turn, this might have a differential impact on different groups of low-income economies, and perhaps force the Asian Drivers to become more inward-oriented, thereby simultaneously raising their demand for imported inputs and reducing competitive pressures in global product markets. A related issue is whether the Asian Drivers handle their currency reserves in ways which might affect the volatility of currencies and macroeconomic performance. In previous eras, volatility has been particularly harmful to lowincome economies (Griffith-Jones et al. 2003).

Flows of productive capital are closely related to production and trade flows. In part, this is through FDI, in which TNCs internalise supply chains in order to serve global markets or to meet the needs of customers abroad. Here the Asian Drivers play a significant role in the competition for funds; in recent years China and Hong Kong have accounted for more than one-third of total FDI flows to the developing world. Also, as Asian Driver-based firms expand their operations, they may become a source of funds for other low-income economies and hence build up a complementary relationship with other developing economies. There is increasing evidence that China in particular is beginning to invest heavily in commodity production and related infrastructure in developing economies.

However, financial flows within firms are not the only source of capital available to expand production. Portfolio flows have been an important source of finance in some countries and sectors. The magnitude and volatile nature of these flows may have profound implications for other developing countries. Here, too, the Asian Drivers may play a combination of competitive and complementary roles. Particularly if they liberalise their capital accounts further, they may become an attractive target for portfolio flows, that they partly squeeze out other emerging economies from global capital markets. On the other hand, when and if domestic and regional financial markets are sufficiently deepened (for example if Asian bond markets are developed), then a higher share of savings from Asian Drivers may remain in their own economy or in other Asian countries, and less would be channelled to the rest of the world, both developed and developing.

\subsection{Environmental externalities}

The very rapid growth of the Asian Drivers has nonmarginal impacts on the environment. These environmental impacts are not only evident within these economies, but also spill over into surrounding regional economies and, in the case of carbon emissions, to the global economy and the biosphere. Many low-income economies are thereby affected both directly and indirectly by the environmental externalities arising from the dynamism of the Asian Drivers.

A major component of these negative externalities is associated with energy, both in the use of carbondisplacing energy, and also in pollution caused by the physical transport of inputs, components and products within the region, and in the region's external trade. The need for energy to fuel economic 
growth has, as observed above, been a major driver in the growing external role played by (often stateowned) firms in energy-surplus regional economies. But it is also reflected in the realm of international relations as the Asian Drivers strive to create an environment to provide for the energy security which has rapidly taken the place of the quest for food security which dominated politics in earlier decades. Partly as a consequence of this search for secure energy supplies and partly because of the environmental externalities of energy-intensive growth, both India and China have begun to play a lead role in the promotion of policy agendas to minimise pollution, and in the development of technologies to lessen their negative impact. This is reflected, inter alia, in their participation in institutions of regional and global governance.

Although energy is a significant component of these spillovers, there is also a range of other environmental externalities arising from the dynamism of the Asian Drivers. For example, water is becoming an increasingly scarce resource, and a possible source of tension with surrounding economies.

\subsection{Global and regional governance}

Overall, the tendency is for global governance to become more complex, to have a greater impact on domestic economies, and for the areas governed to extend. The regulation of various forms of global interchange, in production, trade, finance and the environment, involves a wide range of institutions. For example, the "governance" of global trade increasingly extends beyond governmentdetermined regulations to those defined by private and quasi-private institutions (Nadvi and Waltring 2004). Bodies such as the International Organisation for Standardisation (ISO), the Codex Alimentarus Committee and the World Organisation for Animal Health affect trade through standards setting; the Convention on International Trade in Endangered Species (CITES) regulates trade in endangered species and intellectual property, which is also a trade question and comes under the remit of the World Intellectual Property Organization (WIPO). The global governance of the financial sector is also to an important extent carried out by "soft law", whereby ad hoc bodies such as the Basle Banking Committee agree regulations that strongly influence international bank lending including that to developing countries and domestic bank lending within almost all countries. At present, developing countries are not represented at all on the Basle Banking Committee.

The role played by the Asian Drivers in institutions of global governance has the potential to have major impacts on developing countries. In some cases, this role has already been felt. The impact of China on institutions of global governance was made most visible at Cancun, where it lined up with other leading developing countries (Brazil, South Africa and India), in the formation of the G22. On environmental issues such as climate change, these four countries are grouped with Russia to define the five most influential countries outside of the OECD, each playing a key role in their regions. However, generally, such as in the operations of the Basle Banking Committee and in the deliberations of industry-bodies such as the ISO, the Asian Drivers do not yet have a distinctive voice. But, given their growing size, they are likely to become increasingly active actors in these institutional deliberations.

This growing presence can potentially have significant impacts on other developing economies in different ways. This depends upon whether the role played by the Asian Drivers in institutions of global governance reinforces or opposes the interests of and positions taken by other low-income economies. Already there are examples of these effects. In some cases, the Asian Drivers have acted in concert with other developing economies. For example, India and China could be expected to strongly support the production of generic drugs and their export to developing countries, which would be in the interest of African countries. But in other cases we can anticipate a divergence of interests, for example in relation to Special and Differential Treatment in the WTO (IDS Bulletin 2003). It is likely that the abolition of MFA quotas in the clothing sector will adversely favour China and India at the cost of sub-Saharan African (SSA) producers and this is likely to result in conflicting positions in institutions of global governance. It is also likely that China and India will adopt very different positions in some of these negotiations, with China probably being more likely to align itself with northern positions than India.

\section{Knowledge gaps}

This Asian Drivers research programme addresses a central knowledge gap: what impact will the dynamism of the Asian Drivers have on other 
developing economies? Beneath this meta-question lies a series of general and specific knowledge gaps.

There are three overarching general gaps which this research programme addresses. The first relates to the theoretical framework most appropriate to understanding these issues. At one level, it is evident that this will necessarily be interdisciplinary, multidisciplinary and contextual, for the problems are too complex to be reduced to a single discipline, and the world is too heterogeneous for a single theoretical framework. But there is another level of theoretical challenge: does the rise of the Asian Drivers allow for a coherent overall story on the evolution of the global economy (as in World Systems Theory and other approaches to global political economy), or do we find ourselves in a post-modernist world of contextualism and diverse outcomes? What body of trade-theory or theories explaining the functioning of capital markets best enables an understanding of the issues under investigation? To what extent does our historical research trajectory (e.g. global value chain analysis), help or hinder the understanding of the impact of the Asian Drivers? A second overarching knowledge gap concerns methodology. What methods are most appropriate for analysing and unravelling these complex developments in trade, production, finance, the environment and global governance? To what extent can modelling techniques be used to examine such links? How should existing models best be adapted for this purpose? And, third, there are gaps in our knowledge concerning appropriate policy responses. The significance of the likely impact of the Asian Drivers on other developing countries is such that it is unlikely that previous policies will suffice. But what new policies are required, what new forms of connectedness are indicated between different elements of national policy, in approaches towards institutions of global governance, and in links with other groups of developing economies?

There are also specific knowledge gaps in each of the four vectors which provide the framework for our assessment of the impact of the Asian Drivers on developing economies. We offer some brief examples as an indication of the richness of the research agenda.

\subsection{Production and trade flows}

We know that the dynamic Asian economies have emerged as leading producers and exporters in a number of sectors. They have also become important markets for the imports of various products. We know that these developments are leading to significant shifts in the prices and volumes of traded commodities, manufactures and services. These changes are coming about as a consequence of the productivity and export dynamism of these Asian economies as well as a result of their demand for various raw materials.

What we do not know is how these processes of change in trade flows and terms of trade are affecting other developing countries. The impacts could be both complementary and competitive. In the former case, which countries and which sectors are being drawn into Asian Driver value chains, and who is coordinating this incorporation? Which sectors and countries are gaining directly from the demand of the Asian Drivers for inputs, or (more problematically) indirectly from demand in countries which are directly gaining from the demand generated by the Asian Drivers? To what extent are producers and consumers in other lowincome economies gaining from the price competitiveness and appropriateness of products sourced from the Asian Drivers? On the other hand, trade flows from the Asian Drivers may be competitive to the interests of other developing economies. In which sectors and to what extent are they being crowded out of key markets? In which sectors and to what extent does the competitiveness of the Asian Drivers force down global prices? Over what time-horizon will these impacts be felt; if there is a boom in the prices of some key commodities, how durable will this increase in prices be? And what are the likely consequences of the temporal effects for the many countries in Latin America and Southern Africa who are re-specialising in commodity sectors?

Although part of the wider discussion on trade, the changing distribution and organisation of global production requires further analysis. We know that in a number of sectors where the dynamic Asian economies have emerged as leading global exporters, manufacturers, traders and other private actors are taking on new and enhanced roles in determining the global division of labour, in organising global value chains, and in undertaking more value-added functions. What we do not know is how extensive this is, in which sectors this is most significant, how this is coming about and what consequences arise for the structure and 
organisation of global production. Another aspect of the knowledge gap in this area is the nature of the regional dimension, especially within East Asia, of production organisation and its consequence for the regional division of labour and regional systems of innovation. We also do not know how these new Asian Drivers engage with aspects of global governance, especially governance in the area of public and privately regulated standards. Do the Asian Drivers that organise global and regional production systems act as standards-takers, standards-setters or do they ignore the standards agenda?

\subsection{Financial flows}

An analysis of the way in which the impact of the Asian Drivers on financial flows affects other lowincome economies is particularly beset by the need to take account of macro and indirect affects. While the global economy has witnessed strong growth, allowing for the growing outward orientation of the Asian Drivers, it has done so in the context of large trade imbalances. Growing savings and trade deficits in the US are balanced by significant surpluses among the Asian Drivers; within regions there are also differential patterns of trade performance (e.g. China runs a deficit with its regional neighbours). These surpluses and deficits respond to macroeconomic policies and are accompanied by financial flows, many of which are short term and volatile. But these deficits are also unsustainable. Thus, one big knowledge gap is how these imbalances will be resolved. What are the alternative mechanisms of adjustment (e.g. exchange rate realignment, interest rate policy) required to reduce the fiscal deficit? What is the timing and the speed of such adjustment? To what extent will growth in other regions be able to compensate for the contraction in the US? Who might be the key actors, and what will the implications be for other developing economies, both within the East and South Asian regions, and elsewhere? How will changes in these macroeconomic policies spill over into trade flows? If interest rates in the US increase significantly, how will this affect developing countries especially those with high levels of debt? How will it affect the spreads they have to pay for their borrowing, their capacity to service debts and the possible risk of a currency crisis? What policy responses are appropriate and effective in this world in which the interests of the high-income economies are paramount and in which low-income economies generally have little voice, not least because many of the key decisions are made in the private sector or in the limited fora such as the G7?

These macroeconomic policies have important implications for financial flows. Here there are a range of important knowledge gaps. If the Asian Drivers are to redirect their surpluses away from the dollar, might these surpluses be made available to other developing countries, and if so, to which? What prerequisites of development of local or regional financial markets would have to be met? Another dimension of financial flows are those available to fund investment. What impact might the Asian Drivers have on global portfolio flows? Will their dynamism divert these flows from other developing economies, or from particular groups of developing countries, and through which mechanisms? Or, might they be complementary, perhaps more so in the case of regional economies? What structures in the financial markets lead to different outcomes in portfolio flows?

Another important set of financial flow is FDI. We know that the Asian Drivers are sourcing from other developing countries, we also know that they are emerging in some sectors as leading foreign investors in other developing countries. We do not know yet how extensive and widespread this is, how this varies across sectors and what consequences this has for local producers and workers within these developing countries. In particular, how do firms in other developing countries enter into global value chains dominated by such Asian Drivers, and how do they manage to upgrade within such chains? In addition, in what ways is FDI by the dynamic Asian economies linked into regional economies and agglomeration gains, and to what extent is it driven by trade regimes? And to what extent are FDI flows from the Asian Drivers concentrated in resourceand energy-based sectors?

\subsection{Environmental spillovers}

Unlike production, trade and finance where there has been some preliminary thought on the ways in which the dynamism of the Asian Drivers might affect other countries, less attention has been given to their potential environmental impacts, particularly on other low-income economies.

We know that the rapid growth of the dynamic East and South Asian economies is concentrated in 
the industrial sectors, and is thus materials-intensive. As a consequence, it is leading to significant environmental externalities, both within these countries and globally. We know less about the detailed nature of this environmental footprint, beyond energy (where there has been research on the possible extent and impact of carbon emissions); in what other ways might these spillovers affect other developing countries? Can we distinguish between the direct and indirect effects? Will the production of commodities for the Asian Drivers lead to environmental degradation in the producing countries? Which developing countries are most likely to be affected? What, if any, are the poverty impacts of these spillovers? And over what time-horizon might these externalities be expected to emerge?

\subsection{Global and regional governance}

We know that the Asian Drivers have hitherto not played a major role in institutions of global governance, with the exception of some issues within the framework of the WTO. However, we also know that they are unlikely to sustain this passivity, as reflected in ongoing discussions on the reform of the UN Security Council. There is a significant knowledge gap on whether this historic passivity is reflected in less-visible institutions of global and regional governance, particularly those which do not involve high-level government-togovernment negotiations. There is also a significant gap in understanding the key differences in the approaches adopted by China and India in these various institutions of governance.

Where the Asian Drivers have had a presence in these various types of institutions, have they adopted a common or similar position? Has their role been complementary to, or competitive with the negotiating stands of other low-income economies? This knowledge gap points to our widespread ignorance of the detailed workings in institutions of global governance, a particularly important problem, since in many cases, it is here that outcomes are determined - "the devil lies in the detail". Why and how do the Asian Drivers work to further their individual interests in global institutions such as the WTO, the World Bank and IMF, the UN as well as more regional organisations? How much weight will Asian Drivers place on strengthening regional institutions and mechanisms such as the Asian Development Bank or the Ching Mai initiative in relation to increasing their role in global financial institutions such as the IMF? How do they develop collective interests especially in regional institutions? What drives competitive and complementary actions and how are these moderated by the role played by key countries? To what extent are issues of security - military, energy and food security - affecting the development of regional power blocs, not just in the East Asian region, but in other developing economies? And how do these security concerns reflect themselves in each of the four vectors underlying this research programme?

\section{Methodology}

Addressing these complex problems requires a heterodox mix of methodologies. Some of these may be common across different research questions and in relation to different vectors of impact; others may be specific to particular problems.

The methodological challenge is reflected in the need for interdisciplinary and multidisciplinary research. Given the interconnected nature of the vectors which we have identified, the analytical framework cannot be reduced to economics, but must of necessity involve an integration of disciplinary perspectives and must include a capability to analyse and understand environmental and social factors, and power relations.

A further overarching methodological challenge lies in the necessity of integrating micro-, mesoand macro-levels of analysis. Too often these analytical levels are considered in isolation. Thus, for example, macro-models tend to be ignorant of input-output and power relations at the micro-level and hence despite being intellectually elegant, provide weak insights into the real world. On the other hand, many micro-analyses fail to provide the capacity to generalise, and ignore fallacy of composition problems.

Bearing in mind these needs for interdisciplinarity and the integration of levels of aggregation, a coherent research programme will need to:

- Build on past trajectories of research. There is an existing body of knowledge and analytical techniques which can be used to carry the analysis forward productively. For example, global value chain analysis (developed over the past five years) provides a creative and rigorous framework for analysing global production networks (IDS Bulletin 2001); economy-wide analysis drawing 
on CGE models using the Global Trade and Analysis Project (GTAP) database provides a framework for integrating these value chain analyses into higher-level assessments of the partial and general-equilibrium effects, and into the regional impacts of Asian Driver growth which is both competitive with, and complementary to other low-income economies; past analyses on exchange controls and currency volatility can be used to assess not only the impact of alternative ways in which the Asian Drivers may use their exchange reserves, but also on the implications for flows of portfolio funds and FDI.

- Incorporate both quantitative and qualitative data. Historical and qualitative case-study

\section{Notes}

* The IDS Asian Drivers Team members are: David Evans, Ricardo Gottschalk, Stephany Griffith-Jones, John Humphrey, Jane Kennan, Raphael Kaplinsky, Sherman Robinson, Hubert Schmitz and Christopher Stevens.

\section{References}

Dahlman, C.J. and Aubert, J., 2001, China and the Knowledge Economy: Seizing the 21st Century, Washington, D.C.: World Bank

Griffith-Jones, S., Gottschalk, R. and Cailloux, J. (eds), 2003, International Capital Flows in Calm and Turbulent Times: The Need for a New International Architecture, Ann Arbor, MI: University of Michigan Press

IDS Bulletin, 2003, 'Special and differential treatment in terms of trade', C. Stevens (ed.), assisted by J. Kennan, Vol 34 No 2, Brighton: Institute of Development Studies

IDS Bulletin, 2001, 'The value of value chains: spreading the gains from globalisation', G. Gereffi and R. Kaplinsky (eds), Vol 32 No 3: Brighton: Institute of Development Studies

Kaplinsky, R., 2005, Globalization, Poverty and Inequality, Cambridge: Polity Press

Lall, S. and Abaladejo, M., 2004, 'China's competitive performance: a threat to East Asian analysis is vital for understanding the underlying processes affecting the determinants of production and trade flows, the trajectory of Asian Driver firms and the workings of institutions of regional and global governance. On the other hand, the assessment of the general consequences of these structural features requires extensive data analysis. So, too, will it be necessary to use macroeconomic models to chart the indirect consequences of Asian Driver dynamism on other low-income economies. The analytical challenge is to ensure that as with the micro-meso-macro interface, the qualitative and quantitative discourses are analytically integrated. manufactured exports?', World Development, Vol 32 No 9: 1441-66

Nadvi, K. and Waltring, F., 2004, 'Making sense of global standards', in H. Schmitz (ed.), Local Enterprises in the Global Economy: Issues of Governance and Upgrading, Cheltenham: Edward Elgar

Ng, F. and Yeats, A., 2003, 'Major trade trends in East Asia: what are their implications for regional cooperation and growth?', World Bank Policy Research Working Paper 3084, Washington, D.C.: World Bank, http://econ.worldbank.org/ view.php?type $=5 \&$ id $=27878$ (accessed March 2005)

UNIDO, 2002, Industrial Development Report 2002/2003: Competing Through Innovation and Learning, Vienna: United Nations Industrial Development Organization

Wilson, J., 2002, Liberalizing Trade in Agriculture: Developing Countries in Asia and the Post Doha Agenda, Washington, D.C.: World Bank 